\title{
Author Correction: Hippocampal oxytocin receptors are necessary for discrimination of social stimuli
}

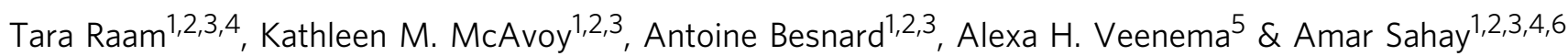

Correction to: Nature Communications https://doi.org/10.1038/s41467-017-02173-0, Article published online 08 December 2017

The original version of this Article contained an error in the spelling of the author Alexa H. Veenema, which was incorrectly given as Alexa Veenema. This has now been corrected in both the PDF and HTML versions of the Article.

Published online: 02 February 2018

\begin{abstract}
(c) (i) Open Access This article is licensed under a Creative Commons Attribution 4.0 International License, which permits use, sharing, adaptation, distribution and ceproduction in any medium or format, as long as you give appropriate credit to the original author(s) and the source, provide a link to the Creative Commons license, and indicate if changes were made. The images or other third party material in this article are included in the article's Creative Commons license, unless indicated otherwise in a credit line to the material. If material is not included in the article's Creative Commons license and your intended use is not permitted by statutory regulation or exceeds the permitted use, you will need to obtain permission directly from the copyright holder. To view a copy of this license, visit http://creativecommons.org/licenses/by/4.0/.
\end{abstract}

(c) The Author(s) 2018

\footnotetext{
${ }^{1}$ Center for Regenerative Medicine, Massachusetts General Hospital, Boston, MA 02114, USA. ${ }^{2}$ Harvard Stem Cell Institute, Cambridge, MA 02138, USA

${ }^{3}$ Department of Psychiatry, Massachusetts General Hospital, Harvard Medical School, Boston, MA 02114, USA. ${ }^{4}$ Program in Neuroscience, Harvard Medical School, Boston, MA 02115, USA. ${ }^{5}$ Department of Psychology, Michigan State University, East Lansing, MI 48824, USA. ${ }^{6}$ Broad Institute of Harvard and MIT, Cambridge, MA 02142, USA. Correspondence and requests for materials should be addressed to A.S. (email: asahay@mgh.harvard.edu)
} 